\title{
Spectrum of Bacterial Isolates and Diagnoses in Physiotherapy and Rehabilitation Facility before and after Armed Conflict in Iraq (Research Note)
}

P. A. Haji (Peri Ali Haji)ㄱ, Z. Dudova (Zuzana Dudova)1', V. Krcmery (Vladimir Krcmery)', P. Tomanek (Pavel Tomanek)'1, T. Hrindova (Tatiana Hrindova)'1, J. Polonova (Jaroslava Polonova)', K. Zoller (Katarina Zoller)'1, D. Dorko (Dominik Dorko)1, B. Durecova (Barbora Durecova)', I. Bartosovic (Ivan Bartosovic)', S. Spanik (Stanislav Spanik)1, N. Bujdova (Natasa Bujdova)', J. Ridosko (Jaroslav Ridosko)2, F. Mellinghoff (Franz Mellinghoff) ${ }^{1}$

${ }^{1}$ Refugee and PhD Program of St. Elisabeth University Erbil, Iraq

${ }^{2}$ University Hospital Trencin, SK

\section{E-mail address:}

peri986@hotmail.com

\section{Reprint address:}

Peri Ali Hajj St. Elisabeth University refugee health and $\mathrm{MSc} / \mathrm{PhD}$ programme

UNHCR Camp 22 Veria

Alexandria, Greece

Suource: Clinical Social Work and Health Intervention

Volume: 8

Issue: 3

Pages: $15-17$

Cited references: 6

\section{Reviewers:}

Daniel J. West

University of Scranton, Department of Health Administration and Human Resources, USA John Mutuku

MIC Nairobi, Kenya

\section{Key words:}

Physiotherapy, Epidemiology, Conflict, War.

\section{Publisher:}

International Society of Applied Preventive Medicine i-gap

CSWHI 2017; 8(3): 15 - 17; DOI 10.22359/cswhi_8_3_02 @ 2017 Clinical Social Work and Health Intervention 


\section{Abstract:}

Etiology and spectrum of diagnoses in the refugee population in the Physiotherapy and Rehabilitation Mobile Clinic is discussed. The Clinic is located in the conflict area of Dohuq, Iraq. The area was largely influenced by Freedom operations in Mosul. Before the conflict, species such as S. aureus, S. pyogenes and S. epidermidis were prevalent. After the conflict, spectrum of bacterial isolates was significantly different; most prevalent species were A. baumanii, Ps. aeruginosa and Enterobacteriaceae.

\section{Conflict of interests:}

The authors whose names are listed in the title of the article certify that they have NO affiliations with or involvement in any organization or entity with any financial interest (such as honoraria; educational grants; participation in speakers' bureaus; membership, employment, consultancies, or other equity interest), or non-financial interest (such as personal or professional relationships, affiliations, knowledge or beliefs) in the subject matter or materials discussed in this manuscript.

\section{Background}

During war conflict in Iraq, some of the facilities previously used for treatment of chronic patients have changed to Acute Departments and Clinics. Armed conflict ongoing in Iraq caused lack of staff and other resources, such as electricity, material and/ or infrastructure. One of these clinics is situated about $15 \mathrm{~km}$ from Mosul and serves as a Rehabilitation Center for war victims.

The aim of this study was to compare the spectrum of bacterial isolates in the patients from the conflict area of Mosul who were treated in the Rehabilitation and Physiotherapy Ward in Dohuq, Iraq.

\section{Patients and methods}

The research group consisted of 197 patients treated after war conflict at the Physiotherapy and Rehabilitation Ward. Medical data of these patients were analyzed and compared to the patients treated before the conflict. EPI-15 System was used for analysis and T-test.

\section{Results and discussion}

In Group 1 (pre-conflict period), majority of the patients had cardiovascular and diabetic complications or non-traumatic wounds, such as lower leg ulcers, erysipelas and others. Most common pathogens found in the swabs collected from the wounds were S. aureus $(7 / 20,35 \%, \mathrm{p}>0.05)$ and $\mathrm{S}$. pyogenes $(6 / 198,3 \%)$. Vice versa, in post conflict group, traumatic or post-traumatic SSTI occurred, mostly after amputations or severe wounds due to bombing. In these wounds, most prevalent species were A. baumanii, Ps. aeruginosa and and Enterobacteriaceae.

\section{Conclusion}

Conflicts largely influence spectrum of bacterial isolates among rehabilitation and physiotherapy patients. In ATB prophylaxis this should be considered as well. 


\section{References}

1. KHALED I, ALI HAJJ P, KRCMERY V, KALATOVA D, GALLOVA A, BAK T, SCHUMMAN I, DUDOVA Z, ZOLLER $\mathrm{K}$, REITH B, OBTULOVIC M, OLAH M, HRINDOVA T, BELOVICOVA M (2017) Spectrum of infections in physiotherapy and rehabilitation ward for war victims and veterans from Iraq and Syria (short note). Clinical Social Work and Health Intervention. 8. 26-28. 10.22359/cswhi_8_2_05.

2. AEILTS GD, SAPICO FL, CANAWATH HN, MALIK GM, MONTGOMERIE JZ (1982) Methicillin-resistant Staphylococcus aureus colonization and infection in a rehabilitation facility. J Clin Microbiol.

3. THOMAS R (2013) MRSA in early rehabilitation - incidence, prevalence and morbidity. Neurol Rehabil. 2013, 19: 118-122.

4. VETKASOV A, HOSKOVA B, SOBOTKOVA I (2015) Reliability of lower motion measurements ribs and diaphragmatic mobility by a radiographic method in people after spinal cord injury. In: Rehabilitácia ISSN 0375-0922, Vol. 52, 2015, No 4, p. 228-235.

5. KIMULI D,CZARNECKI P, MIKLOSKOVA M, SPANIK S, BRYNDZAK $P$ et al (2016) Social pathology II. WMU WARSAW. 2016. 455 pp.

6. BELOVICOVA M, LISKOVA A, HRINDOVA T et al (2017) Low Prevalence of MRSA in Physiotherapy and Gym Facilities in a Greek Refugee Camp. Clinical Social Work and Health Intervention Vol. 8 No. 22017. 